\title{
In vivo qualitative analysis of the biocompatibility of different cyanoacrylate-based adhesives
}

\author{
Rafael Tobias Moretti Neto(a) \\ Isabel Mello(b) \\ Ana Beatriz da Silveira Moretti(c) \\ Carlos Roberto Colombo \\ Robazza ${ }^{(\mathrm{d})}$ \\ Alessandro Antônio Costa \\ Pereira $^{(\mathrm{e})}$ \\ (a) Professor; (d) Head of Endodontics - \\ Department of Clinics and Surgery, School \\ of Dentistry, Federal University of Alfenas \\ (UNIFAL-MG). \\ (b) Doctorate Student in Endodontics, School of \\ Dentistry, University of São Paulo. \\ (c) Doctorate Student in Pediatric Dentistry, \\ School of Dentistry of Bauru, University of \\ São Paulo. Professor of Pediatric Dentistry, \\ School of Dentistry, University of Alfenas \\ (UNIFENAS). \\ (e) Assistant Professor of Pathology, \\ Department of Biological Sciences, School \\ of Dentistry, Federal University of Alfenas \\ (UNIFAL-MG).
}

\begin{abstract}
Cyanocrylates have been widely used in the medical and dental fields for several years. In Dentistry, cyanoacrylates have been used for suturing, pulp capping, as retrofilling material in endodontic surgeries, and as cervical plug for pulpless teeth bleaching. The biocompatibility of these adhesives has been the topic of many researches and subcutaneous implantation is an effective methodology for these studies. The present study evaluated the biocompatibility of three different cyanoacrylate-based adhesives. Thirty-six Wistar rats were used, divided into four groups of 9 animals each: A (control) - distilled water, B - cyanoacrylate ester (Super Bonder), C - n-butyl-cyanoacrylate (Histoacryl) and D - alpha-cyanoacrylate (Three Bond). The materials were dispensed in sponges of polyvinyl chloride, the animals were incised and the sponges were inserted in the subcutaneous tissue and sutured. Each group was sub-divided according to the time of sacrifice of the animals: 7, 21 and 45 days. Subjective analysis of the histologic material showed that all groups presented some degree of irritability, but the inflammatory reaction decreased with the experimental time in all groups. Group D showed an inflammatory reaction which was closer to that of the control group and was considered to have good biocompatibility. Groups B and C were similar and presented more aggressive inflammatory reactions when compared to the control group. Based on the results, it was concluded that alpha-cyanoacrylate (Three Bond) was the most biocompatible adhesive because it caused the lowest levels of inflammation.
\end{abstract}

Descriptors: Adhesives; Inflammation; Subcutaneous tissue; Rats, Wistar.

\section{Corresponding author:}

Carlos Roberto Colombo Robazza

Rua Gabriel Monteiro da Silva, 714, Centro

Alfenas - MG - Brazil

CEP: 37130-000

E-mail: robazza@unifal-mg.edu.br
Received for publication on Aug 04, 2006

Accepted for publication on Jun 04, 2007 


\section{Introduction}

Ideally, every material that is in contact with living tissue must be biocompatible. New materials are constantly being released and demand research to evaluate their properties and commercial viability.

Cyanoacrylates have been used in medicine and dentistry for several years. ${ }^{1}$ It has been proved by many studies that these adhesives can be safely used in sutures, ${ }^{2-6}$ as well as for pulp capping, ${ }^{7}$ and retrofilling material in endodontic surgeries. ${ }^{8-10}$ Their use is recommended for their hemostatic and antiinflammatory features and also for their high adhesion ability in a moist environment. ${ }^{11}$

Concerning biocompatibility, the subcutaneous implantation in animals is the most used methodology due to the following advantages:

1. it does not require a large area for the animals;

2. easy maintenance of the area;

3. simple methodology that does not involve hard tissues, accelerating the laboratorial process;

4. allows to compare the tissue response in the same animal;

5. low costs. ${ }^{12}$

Several authors have employed the subcutaneous implantation test to assess the biocompatibility of different products. ${ }^{13-16}$

As cyanoacrylates can be widely employed in dentistry and they may present some variations in their chemical components, the aim of this study was to analyse the biocompatibility of three cyanoacrylate-based adhesives in subcutaneous tissue.

\section{Material and Methods In vivo analysis (tissue response)}

Thirty-six Wistar rats (Rattus norvegicus albinus) weighing between 200-250 g were used in this study. The animals were anesthetized prior to surgery (Xylazine, Bayer, São Paulo, SP, Brazil; and Ketamine, Parke Davis Ache, São Paulo, SP, Brazil - $0.1 \mathrm{ml}$ for each $100 \mathrm{~g}$ ) and were subjected to hair removal of the dorsal area, followed by disinfection with $0.3 \%$ iodated alcohol. The animals were divided into groups according to the cyanoacrylate tested (Table 1). The substances were dispensed in polyvinyl chloride (PVC) sponges. Three drops of each substance were deposited in the respective sponge.
Table 1 - Experimental groups and substances tested.

\begin{tabular}{l|c|c}
\hline \multicolumn{1}{c|}{ Group } & Substance tested & Trade Mark \\
\hline A (control) & distilled water & - \\
\hline B & ester cyanoacrylate & Super Bonder* \\
\hline C & n-butyl-cyanoacrylate & Histoacryl** $^{*}$ \\
\hline D & Alpha-cyanoacrylate & Three Bond ${ }^{* * *}$ \\
\hline
\end{tabular}

*Loctite, Itapevi, SP, Brazil. **Laboratório B. Braun, São Gonçalo, RJ, Brazil. ***Three Bond do Brasil, Diadema, SP, Brazil.

An incision was made with surgical scissors and each sponge was implanted $15 \mathrm{~mm}$ deep into the subcutaneous tissue of the rat dorsal area. After implantation, the incision was sutured and the animals were kept under observation.

The animals were euthanized with an anesthetic overdose after 7, 21 or 45 days of sponge implantation. The skin containing the sponges and the surrounding tissues were cut and immersed in 10\% formaldehyde for $48 \mathrm{~h}$. After rinsing, the specimens were covered with paraffin, cut into $5 \mu \mathrm{m}$ sections and dyed with hematoxylin-eosine for histological analysis.

The qualitative analysis of the histological sections was done considering the inflammation level and absence or presence and predominance of cell types. The images were submitted to analysis in microscopy (40 X) (Carl Zeiss AG, Jena, Germany) regarding polymorphonuclear (PMN) inflammatory infiltrate, blood vessels, hyperemia and edema (acute inflammation features) and mononuclear $(\mathrm{MN})$ inflammatory infiltrate (lymphocytes, plasmocytes and macrophages). The presence of fibroblasts and less vascularization and edema represented a chronic inflammatory reaction. Another feature analysed was the presence of new-formed blood vessels, which suggests a healing process at the first period, as well as the presence of giant cells and granulomas.

The areas for analysis were selected regarding the phenomena described above, using 20 serial cuts.

\section{Results}

The qualitative analysis showed that at 7 days, groups B and C exhibited characteristics of intense acute inflammation while groups $\mathrm{A}$ and $\mathrm{D}$ showed discrete inflammatory reaction. 
At 21 days, group A showed MN inflammatory infiltrate, fibrosis, granulomatous tissue with several cells and hyperemic blood vessels. Every experimental group showed more intense inflammatory reactions when compared to group A (control), but with differences among them. Group D had a discrete inflammatory infiltrate, presence of granulomatous tissue and some granulomas. The mild response in group D was similar to that of group A. Group B showed some areas of PMN infiltrate and intense MN infiltrate at the peripheral area. Group C showed discrete inflammatory infiltrate near the cavity where the material was deposited and at the peripheral area some granulomatous tissue was identified such as a discrete spot of PMN as shown in Figure 1. An inflammation intensity decrease was noticed in all experimental groups, but group D showed better resolution when compared to the other two groups, which were very similar.

After the 45 day period, group A showed a well organized cavity, filled by mature granulomatous tissue and fibrosis, representing a high level of biocompatibility. Group D presented a cavity with discrete $\mathrm{MN}$ inflammatory infiltrate, granulomatous tissue rich in blood vessels, fibroblasts and granulomas. Groups B and C were alike, with moderate inflammatory infiltrate, mainly MN with a few PMN cells in the cavity and at the peripheral area where there was also granulomatous tissue with vascularization and cells with discrete fibrosis (Figure 2).

\section{Discussion}

Every material for biological use has to be biocompatible. Some studies have been done to assess the biocompatibility of cyanoacrylates both in vivo ${ }^{7,17}$ and in vitro. ${ }^{10}$ However, these adhesives can
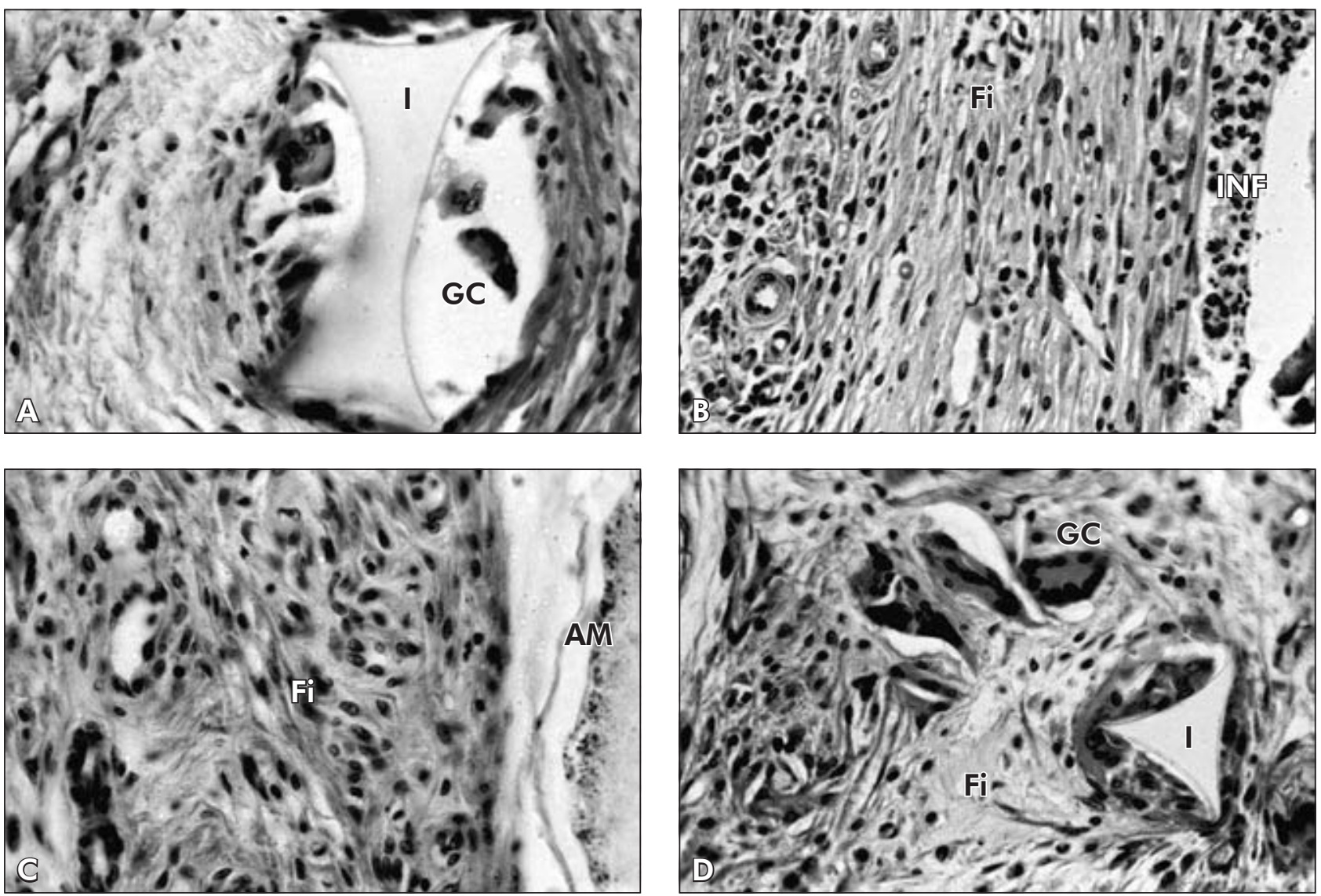

Figure 1 - Microscopic features $(40 X)$ after 21 days. A (Group A) - multinuclear giant cells (GC), foreign body granulomas near the implant (I). B (Group B) - discrete MN and PMN inflammatory infiltrate (INF) and fibrosis (Fi). C (Group C) - amorphous material (AM) and discrete fibrosis (Fi). D (Group D) - multinuclear giant cells. 

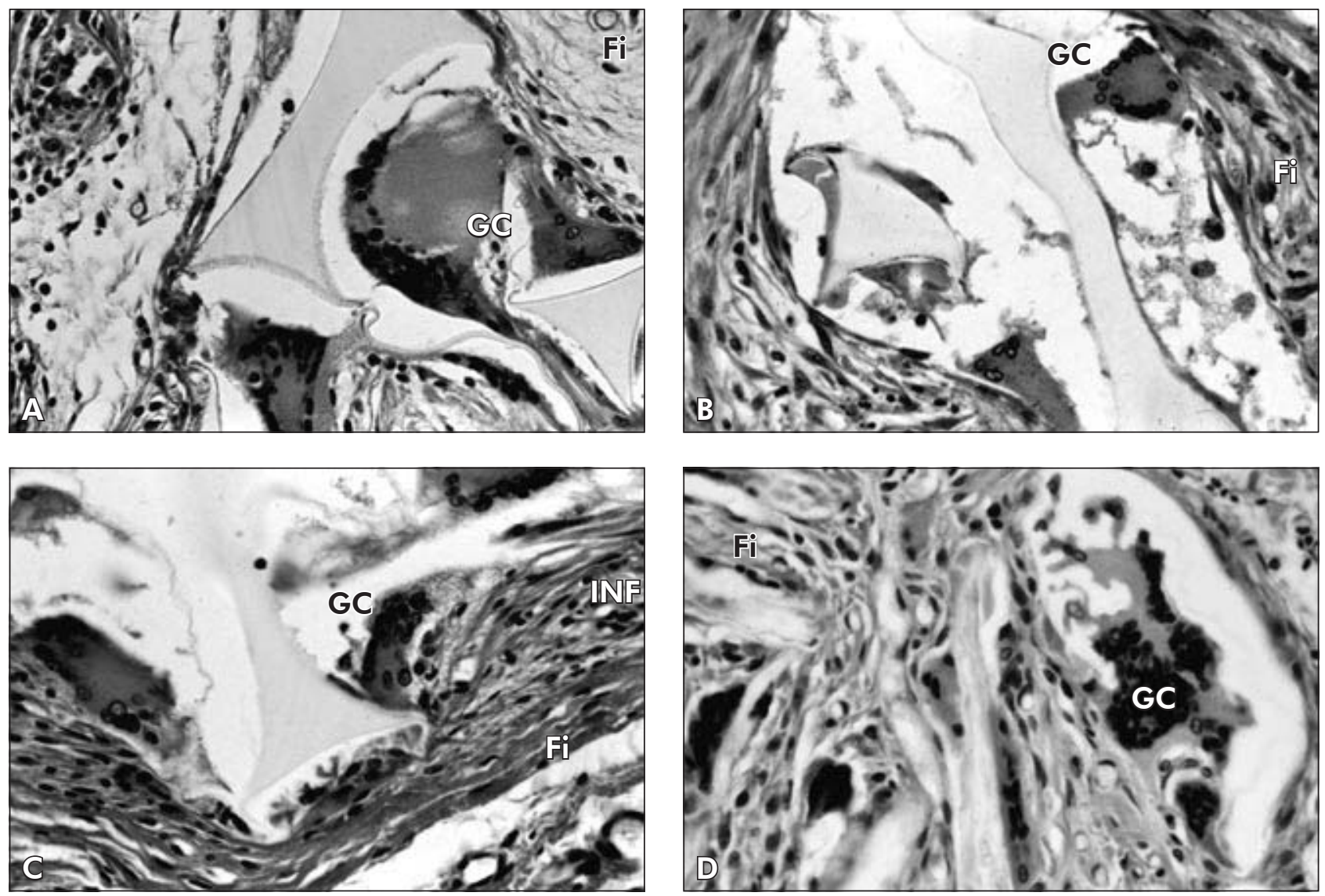

Figure 2 - Microscopic features (40 X) after 45 days. All groups exhibited foreign body granulomas, multinuclear giant cells (GC) and fibrosis (Fi), and different levels of organization among the groups; groups $\mathbf{A}$ and $\mathbf{D}$ exhibited the best results. INF = inflammatory infiltrate.

have different chemical components in their formula and new studies have to be done to assess these variations.

This study evaluated the biocompatibility of cyanoacrylate-based materials by examining their inflammatory reactions after periods of 7, 21 and 45 days after subcutaneous implantation in the dorsal area of rats. This type of subcutaneous implant is widely used and easily reproduced. ${ }^{13-16}$

Acute inflammatory reaction is followed by a chronic inflammatory reaction, if the stimulating agent is not destroyed and eliminated. The longer the acute phase lasts, the more aggressive the agent is. If the stimulating agent still remains, some vascular changes occur and the predominant cell types are macrophages instead of neutrophils or PMN, cells that are typical of the acute phase. The interpreta- tion of vascular phenomena and cell types involved permitted a good evaluation of biocompatibility of the materials tested. When adhesives are compared to conventional methods for closing incisions, they seem to show better results regarding inflammation reactions. Other authors had good results when assessing the biocompatibility of cyanoacrylates and the period for analysis was relevant like in this study. ${ }^{18,19}$

Since the beginning, group D showed more biocompatibility features, similar to those of the control group. Distilled water was used in the control group because it is highly biocompatible. Azevedo et al. ${ }^{10}$ (2003) also compared three cyanoacrylate-based adhesives and the results were similar among the groups after the long-term experimental period. However, after the short period, n-butyl-cyanoacrylate and 
ester cyanoacrylate were more biocompatible. Their findings, regarding the best biocompatibility of the alpha cyanoacrylate, are in agreement with those of our study. The best results of the cyanoacrylates may be explained by the different chemical components present in their formula.

Although all groups presented different levels of inflammation, the reactions decreased as time progressed. Other authors also reported that the period of time was important to the healing process. ${ }^{18,19}$

It was observed that the time was relevant and the inflammation decreased with time in all groups. The healing process occurred more easily in groups

\section{References}

1. Barkhordar RA, Javid B, Abbasi J, Watanabe LG. Cyanoacrylate as a retrofilling material. Oral Surg Oral Med Oral Pathol. 1988;65(4):468-73.

2. Bocca M, Coscia D, Bottalico L, Delpiano IM. Nuove metodiche di sutura in chirurgia orale. Minerva Stomatol. 1999;48(12):633-7.

3. Borba CC, Roubaud Neto E, Val RLR, Borba Jr CO, Soufen MA, Francisco Neto A et al. Uso do cianoacrilato na síntese de pele de ratos: trabalho de pesquisa experimental. Acta Cir Bras. 2000;15(1):48-54.

4. Cooper JM, Paige KT. Primary and revision cleft lip repairs using octyl-2-cyanoacrylate. J Craniofac Surg. 2006;17(2):340-3.

5. Nascimento LMC, Sallum EA, Novaes PD, Nociti Jr FH. Adesivo tecidual (cianoacrilato) na reparação de ferida cirúrgica. Periodontia. 1996;5(4):364-8.

6. Santos GM, Lacaz-Netto R, Santos LM, Okamoto T, Rocha RF. Uso do Super Bonder no reparo de feridas cirúrgicas. RGO. 1990;38(6):435-9.

7. Bhaskar SN, Beasley JD, Ward JP, Cutright DE. Human pulp capping with isobutyl cyanoacrylate. J Dent Res. 1972;51(1):58-61.

8. Araújo SV, Carreira CM, Habitante SM, Carvalho GL, LageMarques JL. Avaliação do selamento em retrobturações com cimentos obturadores associados ou não ao cianoacrilato de etila. Braz Oral Res. 2004;18(Suppl):122.

9. Azevedo CL, Lage-Marques JL, Rode SM, Sá JP. Sealing quality of histoacryl when compared to amalgam as retrofilling. J Endod. 1996;22(4):211.

10. Azevedo CL, Marques MM, Bombana AC. Cytotoxic effects of cyanoacrylates used as retrograde filling materials: an in vitro analysis. Pesqui Odontol Bras. 2003;17(2):113-8.

11. Naves AE. Estudo comparativo da propriedade seladora do cimento N-Rickert associado ou não ao cianoacrilato de etila
A and D, which exhibited organized granulomas and decreasing vascular intensity and cellular phenomena. Groups B and C after 45 days still presented some areas of PMN cells and chronic inflammation and exhibited no cellular organization, no granuloma formation and showed a more intense inflammatory reaction according to the criteria used.

\section{Conclusions}

Based on the results, it was concluded that the alpha-cyanoacrylate (Three Bond) was the most biocompatible adhesive due to the lowest levels of inflammation.

nas obturações retrógradas [Dissertação de Mestrado]. Alfenas: Escola de Farmácia e Odontologia de Alfenas; 1999.

12. Costa CAC. Testes de biocompatibilidade dos materiais odontológicos. In: Estrela C. Metodologia Científica, ensino e pesquisa em odontologia. São Paulo: Artes Médicas; 2001. p. 161-94.

13. Costa CAS, Marchesi M, Benatti Neto C, Bolcrini SC, Gonzaga HFS. Compatibilidade biológica de materiais odontológicos fotopolimerizáveis e quimicamente ativados, utilizados como forradores cavitários (Time Line e Hidro C). Rev Odontol UNESP. 1995;24(1):29-37.

14. Costa CAS, Hebling J, Gonzaga HFS, Benatti Neto C, Spolidório LC. Avaliação comparativa da toxicidade do adesivo dentinário All Bond 2 e do cimento de óxido de zinco e eugenol, quando implantados no tecido conjuntivo subcutâneo de ratos. Rev Fac Odontol Porto Alegre. 1996;37(2):3-6.

15. Costa CAS, Hebling J, Teixeira MF. Estudo preliminar da compatibilidade biológica dos adesivos dentinários All-Bond 2 e Scotchbond Multi Purpose: avaliação histológica de implantes subcutâneo em ratos. Rev Odontol Univ São Paulo. 1997;11(1):11-8.

16. Gomes APM, Ribeiro JF, Nogueira TO. Avaliação da biocompatibilidade de dois adesivos dentinários pelo estudo das reações teciduais em conjuntivo de ratos. Rev Odontol UNESP. 1996;25:135-44.

17. Cotran RS, Kumar V, Collins T. Reparo dos tecidos. In: Cotran RS, Kumar V, Collins T. Patologia estrutural e funcional. $6^{a}$ ed. Rio de Janeiro: Guanabara Koogan; 2000. p. 79-100.

18. Giray CB, Sungur A, Atasever A, Araz K. Comparison of silk sutures and n-butyl-cyanoacrylate on the healing of skin wounds. A pilot study. Aust Dent J. 1995;40(1):43-5.

19. Michelich VJ, Shuster GS, Pashley DH. Bacterial penetration of human dentin in vitro. J Dent Res. 1980;59(8):1398-403. 